\title{
The pharmaceutic capitalization of a natural, marine active principle through in vitro anti-citokinic and proliferative mechanisms of HC-OA osteoarthritic chondrocytes
}

\author{
Laura OLARIU ${ }^{1,2}$, Brindusa DUMITRIU ${ }^{1}$, Toma PAPACOCEA ${ }^{3,4}$, Diana Manuela ENE ${ }^{1}$ \\ ${ }^{1}$ SC Biotehnos SA, Otopeni, Ilfov, Romania \\ ${ }^{2}$ Academy of Romanian Scientists, Bucharest, Romania \\ ${ }^{3}$ Neurosurgery Department, "St. Pantelimon" Emergency Hospital, Bucharest, Romania \\ 4"Carol Davila" University of Medicine and Pharmacy, Bucharest, Romania
}

\begin{abstract}
Osteoarthritis (OA) as a multi-factorial disease that features interrelated mechanisms (senescencel apoptosis, proliferation, decreased synthesis of matrix proteins, activation of degrading enzymes, inflammation) and a diversity of cells involved in bone and cartilage metabolism: chondrocytes, osteoblasts, osteoclasts etc. A complete pharmaceutical solution remains an unsolved question in this interdisciplinary field of research.

We focused our approach on osteoarthritic primary chondrocytes HC-OA (Cell Application), exploring on this primary cell line the small sea fish extract's potential to improve the proliferation rate and to stop the cytokines pro-inflammatory signaling. Previous research results have shown an important therapeutic potential of the small sea fish extract, restoring the intrinsic functionality of the cartilage through its correlative effects: antioxidant and anti-inflammatory action, stimulatory activity of cell proliferation and matriceal proteins homeostasis. In the context of pro-inflammatory and degradative stimulation with IL1 $\beta$, the small sea fish extract prove a counteracting "in vitro" effect, restoring the proliferative capacity of HC$O A$ cells and inhibiting the IL8 release, with implication in several cartilage degradation pathways: MMP13 activation, neutrophils' accumulation, synovium leucocytes activation, as well as the hypertrophic and differentiation processes of chondrocytes.
\end{abstract}

Keywords: small sea fish extract, osteoarthritic chondrocytes, proliferation, pro-inflammatory cytokines, degenerative osteoarthicular diseases

\section{INTRODUCTION}

The increased degradation of cartilage tissue in the joint is caused by the overproduction of enzymes degrading the extracellular matrix, one of the main feature of osteoarthritis, accompaigned by cell proliferation decline and the progression of inflammation. Despite the initial proliferation and activation of chondrocytes, they are not able to efficiently repair the degrading cartilage (1). Abnormal mechanical stress on cartilage induces catabolic and inflammation-related events via intracellular signaling pathways that are similar to those activated by oxidative stress, inflammatory cytokines, and products of matrix damage $(2,3)$. Chondrocytes 
express cytokines and their receptors, as well as MMP-13 and type II collagen cleavage epitopes in regions of matrix depletion in osteoarthritic cartilage. Inflammatory stimuli can also increase either ADAMTS4 or 5 or both, in different experimental models $(4,5)$. Inflammatory cytokines may also induce chemokines, including IL-8, and other cytokines such as IL-6, leukemia inhibitory factor, IL-17, and IL-18. Many of these factors synergize with one another in promoting chondrocyte catabolic responses $(6,7,8)$.

Osteoarthritis (OA) constitutes a widespread health problem and a complete pharmaceutical solution, acting on the main biological mechanisms (chondrocyte senescence or apoptosis, proliferation, decreased synthesis of cartilage matrix proteins, inflammation), remains an unsolved question in the interdisciplinary field of cartilage and bone tissue research.

Alflutop ${ }^{\circledR}$ is a Romanian original drug, haveing as active principle a standardised small sea fish extract, with chondro-restitutive action through the synergysm of its active components. Previous research results have shown an important therapeutic potential of the small sea fish extract, restoring the intrinsic functionality of the cartilage through its correlative efects: antioxidant and anti-inflammatory action, stimulatory activity of cell proliferation and matriceal proteins homeostasis $(9,10)$.

\section{MATERIALS AND METHODS}

Research conducted in SC Biotehnos SA identified new molecular and cellular targets of Alflutop ${ }^{\circledR}$ 's action, relevant in degenerative articular pathologies $(11,12,13)$, but studies has to be continued due to the huge diversity of cells involved in bone diseases: chondrocytes, osteoblasts, osteoclasts etc.

We focused this approach on osteoarthritic primary chondrocytes HC-OA (Cell Application), exploring on this primary cell line the small sea fish extract potential to improve the proliferation rate and to stop the cytokines pro-inflammatory signaling.

Cell culture - Human Chondrocytes Osteoarthritis - HC-OA (Cell Application) - derived from human articular cartilage of donors with OA. HC-OA provides a useful model to explore changes in chondrocyte metabolism in response to abnormal environment of the osteoarthritic joint. Cells were cultivated in Human Chondrocyte Growth Medium at $37^{\circ} \mathrm{C}$, in $95 \%$ humidified air and $5 \% \mathrm{CO}_{2}$ incubator. Cells were treated for $48 \mathrm{~h}$ with different concentrations of small sea fish extract (codified CP) and detached through trypsinization (Trypsin/EDTA 0.1 g\% - Sigma).

\section{Chemical Reagents:}

- BD Cytometric Bead Array (CBA)- Human Inflammatory Cytokines kit (BD Pharmingen)

- Cell Cycle sequentiation (BD Cycletest Plus DNA kit - 340242);

\section{Methods:}

Cell cycle sequentiation, especially the evaluation of mitotic phases: S- DNA synthesis phase and $\mathbf{G} \mathbf{2} / \mathbf{M}$ - the entry in mitosis. The identification of DNA replication cycle is done applying nuclei fluorescence labeling with propidium iodide, followed by flow-cytometric quantification.

Extracellular pro-inflammatory cytokines quantification by flow cytometry (14):

The simultaneous detection of several soluble analytes (inflammatory cytokines) is done through versatile technique that uses a series of discrete fluorescence intensity particles with a capture surface coated with specific antibodies for IL-8, IL-6, IL1 etc. The capture beads, the conjugated detection antibodies and the recombinant standards or assay samples are incubated together to form a sandwich complex that is visualized in APC-A / PE-A coordinates following acquisition of flow cytometry. Analysis of fluorescence histograms and interpolation of values on calibration curves is performed with FCAP Beads Array software.

\section{Equipment:}

- Flow cytometer faCS CANTO II (Becton-Dickinson) with DIVA 6.1., FCS Express and FCAP Array softwares.

- Experiments were performed in triplicate and mean values \pm standard deviation were considered. Graphic representations include the standard deviations between experiments.

\section{RESULTS}

The experimental design is oriented to evaluate the proliferative status of HC-OA cells, in unstimulated conditions, compared with a pro-inflammatory and pro-degradative context induced through IL-1beta stimulation (10 $\mathrm{ng} /$ $\mathrm{ml}, 24 \mathrm{~h}$ ). Cells were cultivated $48 \mathrm{~h}$ prior the addition of the standardized small sea fish extract (codified CP) and another $48 \mathrm{~h}$ with the extract and the corresponding solvent control. 
TABLE 1. HC-OA proliferative status express as cell cycle phases - passage 2

\begin{tabular}{|l|c|c|c|c|c|c|c|c|c|c|}
\hline \multirow{2}{*}{$\begin{array}{l}\text { 2nd passage; } \\
48 \text { h treatment }\end{array}$} & \multicolumn{4}{|c|}{ 2 days treatment without s } & \multicolumn{4}{c|}{ ta $10 \mathrm{ng} / \mathrm{mll} 24 \mathrm{~h}$} \\
\cline { 2 - 12 } & $\% \mathrm{G0} / \mathrm{G} 1$ & $\% \mathrm{~S}$ & $\% \mathrm{G} 2 / \mathrm{M}$ & $\% \mathrm{~S}+\% \mathrm{G} 2 / \mathrm{M}$ & $\begin{array}{c}\text { Varia } \\
\pm \mathrm{G} 2 / \mathrm{M}\end{array}$ & $\% \mathrm{G} 0 / \mathrm{G} 1$ & $\% \mathrm{~S}$ & $\% \mathrm{G} 2 / \mathrm{M}$ & $\% \mathrm{~S} \pm \% \mathrm{G} 2 / \mathrm{M}$ & $\begin{array}{c}\text { Varia } \\
\pm \mathrm{G} 2 / \mathrm{M}\end{array}$ \\
\hline Control cells & 91.3 & 4.76 & 3.94 & $8.7 \pm 0.245$ & 100 & 91.74 & 4.81 & 3.45 & $8.26 \pm 0.118$ & 100 \\
\hline Solvent control 0.2\% & 92.09 & 4.65 & 3.27 & $7.92 \pm 0.2$ & 83.9 & 91.04 & 5.04 & 3.92 & $8.96 \pm 0.151$ & 108.47 \\
\hline Solvent control 0.02\% & 91.55 & 4.49 & 3.96 & $8.45 \pm 0.094$ & 89.89 & 92.69 & 4.03 & 3.29 & $7.32 \pm 0.163$ & 88.62 \\
\hline CP 0.2\% & 92.06 & 4.44 & 3.5 & $7.94 \pm 0.167$ & 84.47 & 92.82 & 3.54 & 3.64 & $7.18 \pm 0.033$ & 86.92 \\
\hline CP 0.02\% & 93.28 & 3.2 & 3.52 & $6.72 \pm 0.184$ & 71.49 & 92.27 & 3.96 & 3.77 & $7.73 \pm 0.167$ & 93.58 \\
\hline
\end{tabular}

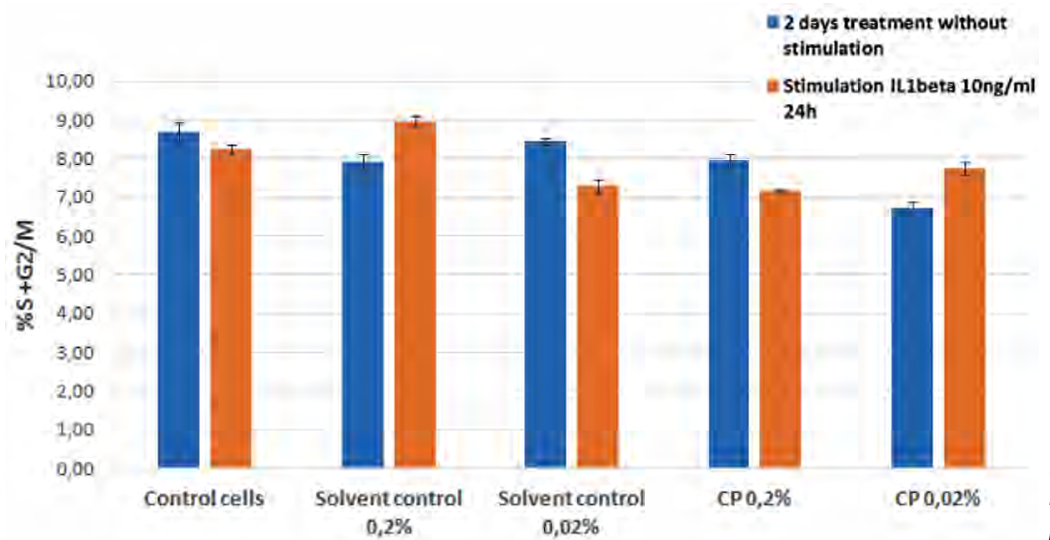

We had to mention that IL-1 $\beta$ is one of the main promoters of the degradation of cartilage, inducing metalloproteinases activation and pro-inflammatory response in osteoarthritis Results are presented in the tables and figures below. The effects were appreciated as \% of variation compared with the cellular control.
Differences of cellular behavior upon IL1-beta stimulation were highlighted in fig. 4, regarding the variation of mitotic progression (cellular $\%$ in $\mathrm{S}$ and $\mathrm{G} 2 / \mathrm{M}$ cell cycle phases). We had to mention that IL-1 $\beta$ is one of the main promoters of the degradation of cartilage, inducing metalloproteinases activation and pro-inflammatory response in osteoarthritis.

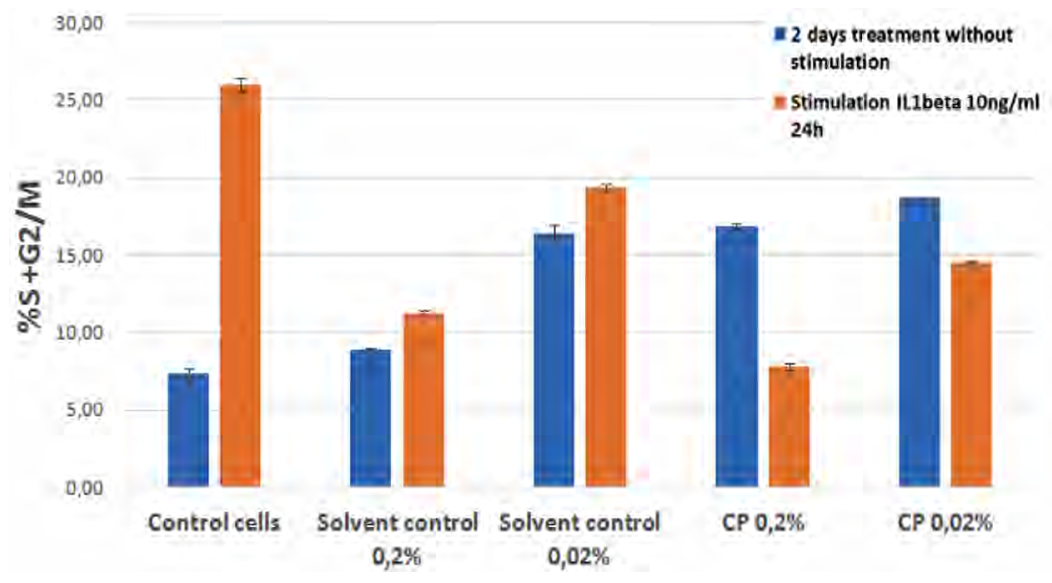

FIGURE 1. Mitotic phases' evolution modulated by the fish extract $(C P)-$ passage 2
FIGURE 2. Mitotic phases' evolution modulated by the fish extract $(C P)-$ passage3

TABLE 2. HC-OA proliferative status express as cell cycle phases - passage 3

\begin{tabular}{|c|c|c|c|c|c|c|c|c|c|c|}
\hline \multirow{2}{*}{$\begin{array}{l}3 \mathrm{nd} \text { passage; } \\
48 \mathrm{~h} \text { treatment }\end{array}$} & \multicolumn{5}{|c|}{2 days treatment without s } & \multicolumn{5}{|c|}{$24 \mathrm{~h}$} \\
\hline & $\% G 0 / G 1$ & $\% \mathrm{~S}$ & $\% G 2 / M$ & $\% \mathrm{~S}+\% \mathrm{G} 2 / \mathrm{M}$ & $\begin{array}{l}\text { Varia } \\
\qquad \pm \mathrm{G} 2 / \mathrm{M}\end{array}$ & $\%$ G0/G1 & $\% \mathrm{~S}$ & $\% G 2 / M$ & $\% \mathrm{~S} \pm \% \mathrm{G} 2 / \mathrm{M}$ & $\begin{array}{l}\text { Varia } \\
\qquad \pm \mathrm{G} 2 / \mathrm{M}\end{array}$ \\
\hline Control cells & 92.81 & 4.04 & 3.51 & $7.55 \pm 0.368$ & 100 & 74.03 & 22.21 & 3.76 & $25.97 \pm 0.396$ & 100 \\
\hline Solvent control $0.2 \%$ & 91.09 & 5.71 & 3.2 & $8.91 \pm 0.073$ & 118.013 & 88.75 & 6.41 & 4.85 & $11.26 \pm 0.159$ & 43.36 \\
\hline Solvent control $0.02 \%$ & 83.57 & 11.82 & 4.61 & $16.43 \pm 0.469$ & 217.616 & 80.62 & 15.78 & 3.6 & $19.38 \pm 0.237$ & 74.62 \\
\hline СР $0.2 \%$ & 83.14 & 12.99 & 3.87 & $16.86 \pm 0.159$ & 223.311 & 92.18 & 3.59 & 4.24 & $7.83 \pm 0.233$ & 30.15 \\
\hline CP $0.02 \%$ & 81.33 & 15.45 & 3.22 & $18.67 \pm 0.082$ & 247.285 & 85.52 & 9.64 & 4.84 & $14.48 \pm 0.155$ & 55.76 \\
\hline
\end{tabular}


TABLE 3. HC-OA proliferative status express as cell cycle phases- passage 6

\begin{tabular}{|c|c|c|c|c|c|c|c|c|c|c|}
\hline \multirow{2}{*}{$\begin{array}{l}\text { 6nd passage; } \\
48 \text { h treatment }\end{array}$} & \multicolumn{5}{|c|}{2 days treatment without $\mathrm{s}$} & \multicolumn{5}{|c|}{ ta $10 \mathrm{ng} / \mathrm{mll} 24 \mathrm{~h}$} \\
\hline & $\% G 0 / G 1$ & $\% \mathrm{~S}$ & $\% G 2 / M$ & $\% \mathrm{~S}+\% \mathrm{G} 2 / \mathrm{M}$ & $\begin{array}{l}\text { Varia } \\
\qquad \pm \mathrm{G} 2 / \mathrm{M}\end{array}$ & $\% G 0 / G 1$ & $\% \mathrm{~S}$ & $\% G 2 / M$ & $\% \mathrm{~S} \pm \% \mathrm{G} 2 / \mathrm{M}$ & $\begin{array}{l}\text { Varia } \\
\qquad \pm \mathrm{G} 2 / \mathrm{M}\end{array}$ \\
\hline Control cells & 86.53 & 10.05 & 3.42 & $13.47 \pm 0.163$ & 100 & 88.92 & 6.48 & 4.61 & $11.09 \pm 0.245$ & 100 \\
\hline Solvent control $0.2 \%$ & 91.33 & 6.37 & 2.3 & $8.67 \pm 0.245$ & 61.02 & 87.5 & 8.72 & 3.78 & $12.5 \pm 0.041$ & 112.71 \\
\hline Solvent control $0.02 \%$ & 87.05 & 9.28 & 3.67 & $12.95 \pm 0.122$ & 68.89 & 89.47 & 6.33 & 4.2 & $10.53 \pm 0.139$ & 94.95 \\
\hline CP $0.2 \%$ & 74.7 & 18.81 & 6.49 & $25.3 \pm 0.327$ & 139.64 & 71.61 & 19.811 & 8.59 & $28.4 \pm 0.245$ & 256.09 \\
\hline CP $0.02 \%$ & 74.02 & 17.01 & 8.97 & $25.98 \pm 0.057$ & 162.93 & 72.24 & 17.43 & 10.33 & $27.76 \pm 0.163$ & 250.32 \\
\hline
\end{tabular}

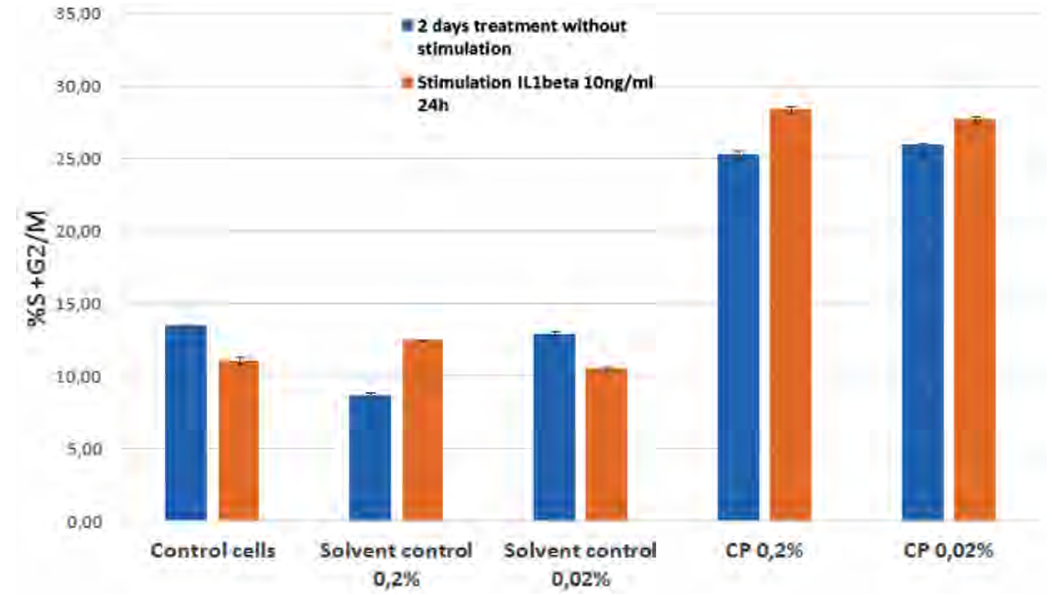

FIGURE 3. Mitotic phases' evolution modulated by the fish extract (CP) passage 6

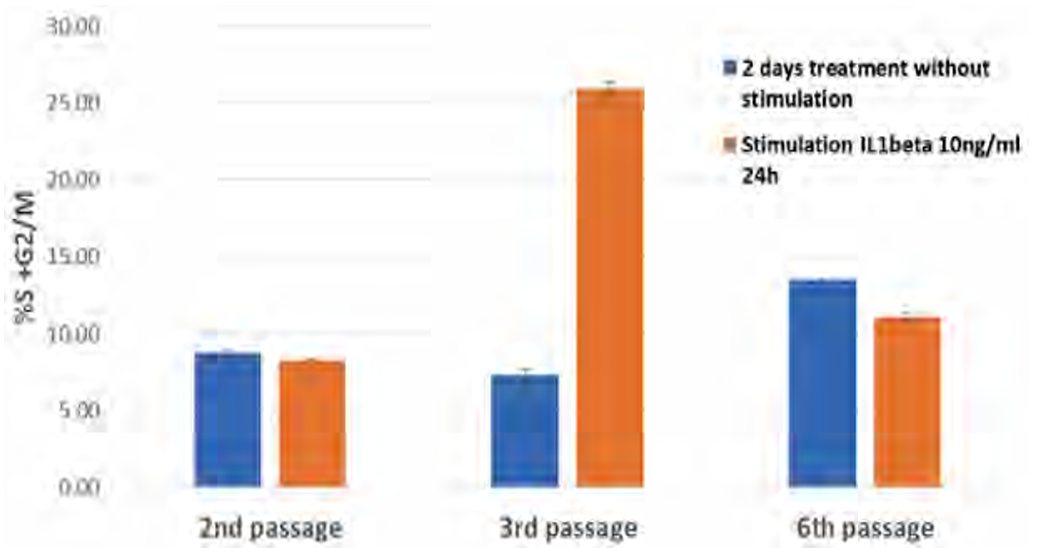

FIGURE 4. HC-OA chondrocytes ageing correlated with the proliferative response to IL1-beta stimulation
The pro-inflammatory response of IL1-beta stimulation was quantified in the terms of IL6, II8, IL1-alpha and IL1-beta extracellular release, as main mediators of osteoarthicular inflammation. Cytokines are transiently produced by most cells, including chondrocytes, in response to cellular activation signals. They produce effects in the paracrine manner on the adjacent tissue or cells, or on the cells from which they were secreted, in the autocrine manner. TNF- $\alpha$ and IL-1 do not act isolated, but as a result of IL6 and IL8 interaction, producing chain reactions (metalloproteinase production, activation of re- active oxygen species etc.), resulting cartilage degradation (15).

IL6, besides the role of active participant in degenerative joint processes, has pluripotent functions in immunomodulation, regulation of cell growth and differentiation, induction of inflammation (16).

Studies of extracellular pro-inflammatory cytokines have been performed on the osteoarthritic chondrocyte cell line at different passages. The results obtained are presented in the tables below, with a special mention for IL1 $\beta$. In series stimulated with IL1-beta $10 \mathrm{ng} / \mathrm{ml}$ we cal- 
TABEL 4. HC-OA Cytokines profile at passage 2

\begin{tabular}{|c|c|c|c|c|c|c|c|c|c|c|c|c|}
\hline \multirow{2}{*}{$\begin{array}{l}\text { 2nd passage; } \\
48 \mathrm{~h} \text { treatment }\end{array}$} & \multicolumn{3}{|c|}{ IL8 (pg/ml) } & \multicolumn{3}{|c|}{ IL6 (pg/ml) } & \multicolumn{3}{|c|}{ Hlalfa (pg/ml) } & \multicolumn{3}{|c|}{ IL1 beta (pg/ml) } \\
\hline & $\begin{array}{c}\text { unstimu- } \\
\text { lated }\end{array}$ & stimulated & $\begin{array}{c}\% \\
\text { variation }\end{array}$ & $\begin{array}{c}\text { unstimu- } \\
\text { lated }\end{array}$ & stimulated & \begin{tabular}{|c|}
$\%$ \\
variation
\end{tabular} & $\begin{array}{c}\text { unstimu- } \\
\text { lated }\end{array}$ & \begin{tabular}{|c|} 
stimu- \\
lated
\end{tabular} & \begin{tabular}{c|}
$\%$ \\
variation
\end{tabular} & $\begin{array}{l}\text { unstimu- } \\
\text { lated }\end{array}$ & stimulated & $\begin{array}{c}\% \\
\text { variation }\end{array}$ \\
\hline Control cells & 7254.57 & $41231.48 \pm 8.16$ & 100.00 & 552.51 & $8497.46 \pm 11.08$ & 100.00 & 513.58 & $681.02 \pm 16.33$ & 100.00 & 1323.13 & $1493.13 \pm 31.13$ & 100.00 \\
\hline Solvent control $0.2 \%$ & 7404.02 & $41651.98 \pm 9.80$ & 101.00 & 639.89 & $8569.87 \pm 16.33$ & 100.90 & 844.58 & $633.35 \pm 24.21$ & 93.00 & 1563.76 & $1459.17 \pm 23.75$ & 97.70 \\
\hline Solvent control $0.02 \%$ & 8969.92 & $10315.69 \pm 12.17$ & 978.00 & 763.87 & $8517.23 \pm 15.51$ & 100.20 & 696.55 & $600.52 \pm 16.33$ & 88.20 & 1436.76 & $1414.41 \pm 15.92$ & 94.70 \\
\hline CP $0.2 \%$ & 7027.96 & $19518.73 \pm 4.70$ & 95.80 & 639.89 & $88883.41 \pm 24.49$ & 104.50 & 711.92 & $665.32 \pm 13.06$ & 97.70 & 1414.41 & $1504.6 \pm 14.40$ & 100.80 \\
\hline CP $0.02 \%$ & 7404.02 & $|18315.69 \pm 10.61|$ & 92.90 & 569.89 & $8490.87 \pm 17.95$ & 99.90 & 681.02 & $649.43 \pm 40.82$ & 95.40 & 1436.76 & $1436.76 \pm 27.88$ & 96.20 \\
\hline
\end{tabular}

TABEL 5. HC-OA Cytokines profile at passage 3

\begin{tabular}{|c|c|c|c|c|c|c|c|c|c|c|c|c|}
\hline \multirow{2}{*}{$\begin{array}{l}\text { 3nd passage; } \\
48 \text { h treatment }\end{array}$} & \multicolumn{3}{|c|}{ IL8 (pg/ml) } & \multicolumn{3}{|c|}{ IL6 (pg/ml) } & \multicolumn{3}{|c|}{ IL1 alia (pg/ml) } & \multicolumn{3}{|c|}{ IL1 beta (pg/ml) } \\
\hline & $\begin{array}{l}\text { unstimul- } \\
\text { ated }\end{array}$ & stimulated & $\begin{array}{c}\% \\
\text { variati }\end{array}$ & $\begin{array}{l}\text { unstimu- } \\
\text { lated }\end{array}$ & stimulated & $\begin{array}{c}\% \\
\text { variati }\end{array}$ & $\begin{array}{l}\text { unstimu- } \\
\text { lated }\end{array}$ & $\begin{array}{l}\text { stimu- } \\
\text { lated }\end{array}$ & \begin{tabular}{c|}
$\%$ \\
variati
\end{tabular} & $\begin{array}{l}\text { unstimu- } \\
\text { lated }\end{array}$ & $\begin{array}{l}\text { stimu- } \\
\text { lated }\end{array}$ & $\begin{array}{c}\% \\
\text { variatic }\end{array}$ \\
\hline Control cells & 6798.37 & $41784.72 \pm 61.24$ & 100 & 517.92 & $8925.56 \pm 26.96$ & 100 & $633.35 \pm 40.27$ & 649.32 & 100 & 1459.17 & $1436.76 \pm 25.07$ & 100 \\
\hline Solvent control $0.2 \%$ & 6875.24 & $41737.3 \pm 32.21$ & 99.9 & 817.44 & $8766.29 \pm 50.92$ & 98.2 & $416.25 \pm 22.61$ & 617.05 & 95 & 1436.76 & $1369.4 \pm 40.82$ & 95.3 \\
\hline Solvent control $0.02 \%$ & 8204.11 & $41547.33 \pm 94.14$ & 99.4 & 970.19 & $8746.72 \pm 38.26$ & 98 & $764.6 \pm 22.54$ & 681.02 & 104.9 & 1481.75 & $1601.32 \pm 25.89$ & 111 \\
\hline CP $0.2 \%$ & 8764.26 & $30906.67 \pm 46.28$ & 74 & 1386.33 & $8831.42 \pm 36.84$ & 98.9 & $815.84 \pm 46.65$ & 657.17 & 101.2 & 1747.23 & $1504.6 \pm 22.13$ & 104.7 \\
\hline CP $0.02 \%$ & 7478.27 & $37975.82 \pm 61.24$ & 90.9 & 763.87 & $8909.36 \pm 27.55$ & 99.8 & $522.65 \pm 16.08$ & 566.68 & 87.3 & 1425.58 & $1425.58 \pm 25.30$ & 99.2 \\
\hline
\end{tabular}

TABLE 6. HC-OA Cytokines profile at passage 6

\begin{tabular}{|c|c|c|c|c|c|c|c|c|c|c|c|c|}
\hline \multirow{2}{*}{$\begin{array}{l}\text { 6nd passage; } \\
48 \text { h treatment }\end{array}$} & \multicolumn{3}{|c|}{ IL8 (pg/ml) } & \multicolumn{3}{|c|}{ IL6 (pg/ml) } & \multicolumn{3}{|c|}{ ILlalfa (pg/ml) } & \multicolumn{3}{|c|}{ IL1 beta (pg/ml) } \\
\hline & $\begin{array}{c}\text { unstimu- } \\
\text { lated }\end{array}$ & stimulated & $\begin{array}{c}\% \\
\text { variation } \\
\end{array}$ & $\begin{array}{c}\text { unstimu- } \\
\text { lated }\end{array}$ & stimulated & $\begin{array}{c}\% \\
\text { variation } \\
\end{array}$ & $\begin{array}{c}\text { unstimu- } \\
\text { lated }\end{array}$ & stimulated & $\begin{array}{c}\% \\
\text { variatlor }\end{array}$ & $\begin{array}{c}\text { unstimu- } \\
\text { lated }\end{array}$ & stimulated & $\begin{array}{c}\% \\
\text { variatior } \\
\end{array}$ \\
\hline Control cells & 8969.92 & $41499.66+43.79$ & 100.00 & 1440.59 & $9009.67+43.41$ & 100.00 & 649.43 & $711.92 \pm 18.47$ & 100.00 & 1504.60 & $1459.17 \pm 50.78$ & 100.00 \\
\hline Solvent control $0.2 \%$ & 7772.18 & $42819.94+28.50$ & 103.20 & 871.22 & $8707.53 \pm 26.32$ & 96.60 & 696.55 & $717.05 \pm 32.79$ & 100.70 & 1459.17 & $1436.76+40.38$ & 98.50 \\
\hline Solvent control $0.02 \%$ & 7103.83 & $40766.88+56.60$ & 98.20 & 1042.40 & $8424.84+28.77$ & 93.50 & 772.00 & $681.02 \pm 39.56$ & 95.70 & 1551.63 & $1576.07+31.92$ & 108.00 \\
\hline CP $0.2 \%$ & 7917.33 & $40453.64+45.76$ & 97.50 & 1268.65 & $8736.92 \pm 29.49$ & 97.00 & 711.92 & $742.22 \pm 32.06$ & 104.30 & 1576.07 & $1504.6+17.20$ & 103.10 \\
\hline CP $0.02 \%$ & 8345.79 & $40864.18+52.81$ & 98.50 & 1205.26 & $8746.72 \pm 46.96$ & 97.10 & 583.74 & $681.02 \pm 32.20$ & 95.70 & 1369.40 & $1481.75 \pm 36.6$ & 101.50 \\
\hline
\end{tabular}

culated this cytokine concentration subtracting this value from the final result.

\section{DISCUSSION}

$\mathrm{IL}-1 \beta$ is one of the most important cytokine involved in osteoarthritis pathogenesis and it is widely used for in vitro inflammation models, to screen drugs or natural compounds. IL-1 is capable of inducing chondrocytes and synovial cells to synthesize MMPs, suppresses the synthesis of type II collagen and proteoglycans, and inhibits transforming growth factor- $\beta$ stimulated chondrocyte proliferation. It acts through an in situ mechanism, in a paracrine or in an autocrine way (17).

Our study on the primary line of osteoarthritic chondrocytes reveals different effects of IL-1 stimulation, dependent of the cell evolution, from the beginning of cell maturity (passage 2), to the functional status decline (passage 6).
The HC-OA cell line is form of primary cells from osteoarthritic patients and has a limited time of preserving the normal physiological status, including the proliferative one.(fig.no.1). This is the reason of the decrease of responsivity at the higher passages. At passage 2, the IL1- $\beta$ stimulation doesn't disturb the mitotic rate. The stimulation effect is counteracted at this level by the cellular intrinsic regulatory mechanisms. At passage 3, the IL1-beta stimulation accelerates the DNA synthesis, leading to hypertrophic chondrocytes. In this case, the fish extract (CP) stimulates the cells division only in the unstimulated conditions, and decrease the proliferation in IL- $1 \beta$ activated cells, preventing the abnormal bone formation. At the $6^{\text {th }}$ passage, when the proliferation rate is lower and metabolic status decline, CP activates the osteoarthritic chondrocytes turn-over in both stimulated and unstimulated experimental series. This is a significant action, considering that osteoarthritis is charac- 
terized by the endochondral ossification and by a "senescence-associated secretory phenotype "characterized by the secretion of interleukin-1 (IL-1) and interleukin-6 (IL-6), as well as matrix metalloproteinase-3 (MMP-3) and-13 (MMP$13)$, and the regenerative capacity of OA chondrocytes is lost (18). We must remark that the fish extract doesn't stimulates the mature chondrocytes that have a normal division cycle, but only the cells that are in a decline state.

IL-1 $\beta$ production was detected in medial and lateral primary chondrocyte cultures; however, the concentration of this cytokine was highest in the cultures established from the region of greatest pathology. (19) It was demonstrated that IL-1beta is the initiator of several cascades of pro- inflammatory cytokines, IL-6 and IL 8 being the most significant. IL8 expression in human osteoarthritic chondrocytes is a clinical predictive marker and a possible target, in the treatment of arthritic diseases (20).

We decided to monitor in our experimental design IL6 and IL8 release, as essential promoters of the inflammatory response, as well as the two IL1cytokines, IL $1 \alpha$ and IL1 $\beta$ There are scientific evidences that indicate increased IL-1 $\alpha$ in cartilage is associated with early degenerative changes, suggesting an autocrine/paracrine role for this cytokine in osteoarthritic pathogenesis (21). The other similar protein, IL1 $\beta$ is the more potent form of the pro-degradative cytokine IL1, both having synergistic effect in cartilage injuries (22).

Our "in vitro" study reveals only a slow response in terms of IL1 autocrine stimulation in the metabolic active status of the cells (passages 2 and 3), but a very high release of IL6 and IL8 after a $24 \mathrm{~h}$ pro-inflammatory conditions (IL1 paracrine stimulation of cytokines) in every stage of osteoarthritic chondrocytes development. The fish extract is not active at passage 2, or at the ending of osteoarthritic chondrocytes development (passage 6). It inhibits IL8 release from HC-OA cells cultivated at passage 3 , a mature stage of cell development, an importing effect having in mind the role of IL8 chemokine in MMP13activation, neutrophils' accumulation, synovium leucocytes activation, as well as the hypertrophic and differentiation processes of chondrocytes.

These effects could be compared with the others reported by the scientific literature for compounds used as anti-cytokines agents in osteoarthritic therapy: glucosamine (23), schisandrin A (24), caffeic acid (25), diacerein (26) etc.

\section{CONCLUSIONS}

The osteoarthritic chondrocytes - HC-OA, studied as cellular model for active principles interactions in disease, has proven biological relevance as responsiveness to pro-inflammatory stimulation and IL6 and IL8 release, as well as proliferative behavior function the stage of cellular development (passage 2 compared to passage 6).

In the context of pro-inflammatory and degradative stimulation with IL1 $\beta$, the small sea fish extract prove a counteracting "in vitro" effect, restoring the proliferative capacity of HC-OA cells and inhibiting the IL8 release. These experimental data must be projected as an addition of a new cellular model with biological relevance in the background of already existing evidences on several standardized lines and primary cells (CHON-001, HCH-human normal chondrocytes). Results confirm on osteoarthritic chondrocytes the small sea fish extract's effects previously proved, especially the regeneration capacity and the anti-cytokine action.

Future experiments should explore the other interrelated metabolic pathways of osteoarthritic chondrocytes in order to explain and sustain the pharmacological action of the standardized fish extract on this cellular model.

Conflict of interest: none declared Financial support: none declared

\section{REFERENCES}

1. MB Goldring, SR Goldring. Osteoarthritis. J Cell Phys, 213 (2007), pp. 626-634

2. P Bernstein, $C$ Stich, A Jacobi, C Liebers. Expression pattern differences between osteoarthritic chondrocytes and mesenchymal stem cells during chondrogenic differentiation. Osteoarthritis and Cartilage, Volume 18, Issue 12, 2010, 1596-1607
3. T Papacocea, I Buraga, R Papacocea, Al Badarau, M Buraga, C Ciornei, G Mihai, I Stoian, D Adam. Antioxidant enzymespotential targets in intracerebral haemorrhage. Farmacia, 62(6), 1118-1125 (2014).

4. Gabay O, Sanchez C, Salvat C, Chevy F, Breton M, Nourissat G et al. (2010) Stigmasterol: A phytosterol with potential anti-osteoarthritic properties. Osteoarthritis Cartilage, 18: 106-116

5. Sato T, Konomi K, Yamasaki S, Aratani S, Tsuchimochi K, Yokouchi M et al. (2006). Comparative analysis of gene expression profiles in intact and damaged regions of human osteoarthritic cartilage. Arthritis Rheum 54: 808-817 
6. Goldring MB. Chondrogenesis, chondrocyte differentiation, and articular cartilage metabolism in health and osteoarthritis. Ther Adv Musculoskelet Dis. 2012; 4(4):269-85

7. K Huang, LD Wu. Aggrecanase and aggrecan degradation in osteoarthritis: A review. J Int Med Res, 36 (2008), pp. 1149-1160

8. JP Pujol, C Chadjichristos, $F$ Legendre, $C$. Bauge, G Beauchef, R Andriamanalijaona. Interleukin-1 and transforming growth factor-beta 1 as crucial factors in osteoarthritic cartilage metabolism. Connect Tissue Res, 49 (2008), pp. 293-297

9. L Olariu, B Dumitriu, DM Ene, A Pavlov, N Pyatigorskaya, N Rosoiu. ALFLUTOP ${ }^{\circledR}$ modulates "in vitro" relevant mechanisms of osteoarthritic pathology. Academy of Romanian Scientists, Annals Series on Biological Sciences, 6(1), 82-99, 2017

10. ML. Craciun, MD Ene, E Buse, $N$ Pyatigorskaya, A Pavlov, L Olariu. Cellular and molecular effects of a small sea fish extract on hyaluronan homeostasis. The FEBS Journal 284 (Suppl. 1), pag. 382, 2017

11. Emilia Buse, Brandusa Dumitriu, Laura Olariu, Diana Ene, Mihai Bojinca, Toma Papacocea. Cellular and molecular activity of a standardized small sea fish extract in an experimental model of primary human cartilage cells. Romanian Journal of Rheumatology, volume XXVII, no. 1, 2018

12. Laura Olariu, Emilia Buse, Brandusa Dumitriu, Luiza Maria Craciun, Sorin-Valeriu Draga-Coleta, Raluca Papacocea. New cellular and molecular effects, relevant for osteoarthicular pathology, proved for and Romanian original product on specific, predictive, in vitro systems. lasi, 19 mai 2018, Euroinvent (gold medal)

13. Laura Olariu, Brandusa Dumitriu, Luiza Craciun, Emilia Buse, Natalia Rosoiu, Mihai
Bojinca, Toma Papacocea. The in vitro influence of a pharmaceutically active small sea fish extract on apoptosis and proliferation mechanisms amplified by inflamatory conditions. Farmacia, 2018, vol. $66,(3)$

14. Cook EB, Stahl JL, Lowe L, Chen R, Morgan E, Wilson J, Varro R, Chan A, Graziano FM, Barney NP. Simultaneous measurement of six cytokines in a single sample of human tears using microparticlebased flow cytometry: Allergics vs. non-allergics. Journal of Immunological Methods, 2001, 254, (1-2), 109-118.

15. Y Yang, S-G Gao, F-J Zhang, W Luo, J-X Xue, G-H Lei. Effects of osteopontin on the expression of IL-6 and IL-8 inflammatory factors in human knee osteoarthritis chondrocytes. European Review for Medical and Pharmacological Sciences, vol. 18, no. 23, pp. 3580-3586, 2014.

16. Yves Henrotin, Donat De groote, Alain Labasse, Simone Gaspar, Shao-Xiong Zheng, Vincent Geenen, Jean-Yves Reginster. Effects of exogenous IL-I, TNF , IL-6, IL-8 and LIF on cytokine production by human articular chondrocytes. Osteoarthritis and Cartilage (1996) 4 , 163-173,1996

17. A Melo-Florián. IL-1 and its role in osteoarthritis, Open Journal of Medicine, 2011 Vol. 1 No. 1:3

18. Sharma AR, Jagga S Lee, SS Nam JS (2013). Interplay between cartilage and subchondral bone contributing to pathogenesis of osteoarthritis. International journal of molecular sciences, 14(10), 19805-30.

19. X Lozano-Torres, AL Buckley, L Miller, G Bundens, V Datillo, LB Milton, K Behling, S Chmielewski, E Cho, A Selim. Production Of Interleukin 1 Beta In Primary, SerumFree Cultures Of Human Osteoarthritic Chondrocytes, Mindy George-Weinstein, and Marina D'Angelo. The FASEB Journal 30:1_supplement, 1039.7-1039.7, 2016

20. Takahashi $A$ et al. Epigenetic regulation of interleukin-8, an inflammatory chemokine, in osteoarthritis. Osteoarthritis and Cartilage, Volume 23, A191 - A192

21. CA Towle, Han HwaHung, LJ Bonassar, Benjamin V, D Treadwell. C Mangham. Detection of interleukin-1 in the cartilage of patients with osteoarthritis: A possible autocrine/paracrine role in pathogenesis. Osteoarthritis and Cartilage, Volume 5, Issue 5, 1997, 293-300

22. Jotanovic Z, Mihelic R, Sestan B, Dembic $Z$. Role of interleukin-1 inhibitors in osteoarthritis: an evidence-based review. Drugs.Aging, 2012, 1;29(5):343-58.

23. Largo $R$ et al. Glucosamine inhibits IL-1 beta-induced NFkappaB activation in human osteoarthritic chondrocytes. Osteoarthritis and Cartilage, Volume 11, Issue 4, 290 - 298

24. Tu C, Huang $X$, Xiao $Y$, Song M, Ma Y, Yan $\mathrm{J}$, You H, Wu H. Schisandrin A Inhibits the IL-1ß-Induced Inflammation and Cartilage Degradation via Suppression of MAPK and NF-kB Signal Pathways in Rat Chondrocytes. Front Pharmacol., 2019, 10:41.

25. Huang X, Xi Y, Pan Q, Mao Z, Zhang R, Ma $X$, You $H$. Caffeic acid protects against IL-1 $\beta$-induced inflammatory responses and cartilage degradation in articular chondrocytes, Biomed Pharmacother. 2018 Nov;107:433-439. doi: 10.1016/j. biopha.2018.07.161. Epub 2018 Aug 10..

26. Yaron M, Shirazi I, Yaron I. Antiinterleukin-1 effects of diacerein and rhein in human osteoarthritic synovial tissue and cartilage cultures. Osteoarthritis Cartilage. 1999 May;7(3):272-80. 